meat. To compute the production cost an equation was constructed, where the traits were included as variables. Using this equation the production cost per $\mathrm{kg}$ lean meat can be computed at different levels of the variables. To obtain the proper mathematical expression of the financial effect of changes in the variables, the partial derivative of the equation was computed for each of the traits referred to. These expressions directly show the financial value of each trait per unit of change at different levels of the variables. The stability of the economic weights has been investigated. The frequence and points of time of the monetary returns from breeding as well as the influence on the genetic gain of different or incorrect economic weights have been discussed.

\title{
ESTIMATION OF ECONOMIC VALUES OF PERFORMANCE CHARACTERS IN PIG AND SHEEP BREEDING
}

\author{
R. SILER, $Z$. PODEBRADSKY, V. JAKUBEC \\ Research Institute of Animal Production, Praha Io-Uhrineves, Czechoslovakia
}

Hybridisation programmes are mostly realized by means of three levels of herds where breeding animals used in elite herds are deciding. In the consequence of the high reproduction rate in the pig it is possible to produce $700-800$ final hybrids per sow and year in elite herds. In Czechoslovak conditions $73 \mathrm{p}$. 100 of the total cost is expended on the own fattening, $2 \mathrm{I}$ p. Ioo on sow breeding in commercial herds (i.e. 94 p. Ioo on the third level of final hybrids production), $5 \mathrm{p}$. I0o on multiplier herds and I p. Ioo only on elite herds. It is therefore possible to evaluate the effectiveness of the hybridisation programme on the basis of results achieved in the last production level.

In the sheep with much lower reproduction rate is the situation qualitatively different. In a specialized large scale unit for lamb production within the closed system of breeding about $20 \mathrm{p}$. Ioo of the total cost is expended on the breeding of pure lines, $45 \mathrm{p}$. Ioo on the breeding of $F_{1}$ females and $35 \mathrm{p}$. roo on the own fattening. The calculation of a profit function is here therefore much more complicated. An example of the construction of a multifactorial function is presented. It includes four groups of basic production parameters and five categories of animals only compared with the practical situation where $z 2$ categories are necessary.

THE USE OF PRODUCTION SYSTEMS ANALYSIS

IN DEVELOPING SELECTION GOALS AND METHODS

J. W. WILTON

Department of Animal and Poultry Science, University of Guelph, Guelph, Ontario, Canada.

Production systems analysis is described, its present applications are discussed and its uses in determining selection goals and methods are discussed. The key features of systems analysis are the statement of a well-defined objective, the accurate representative of real-life production programs and the use of alternative procedures by decision makers. Measurements that have been suggested to describe selection goals are discussed and compared with the objectives specified in systems analysis. Selection procedures that have been used for these various measurements are also discussed and compared with methods that could be used in systems analysis.

\section{PROCÉdURES DE DÉFINITION DES OBJECTIFS DE SÉLECTION}

\section{J. MALLARD}

Chaive de Génétique, E.N.S.A. de Rennes, 65, rue de St-Brieuc, 35000 Rennes

L'objectif d'une sélection est un ensemble complexe de nombreuses exigences exprimées sous forme soit de pondérations liant les caractères, soit de gains génétiques à réaliser pour certains caractères ou ensembles de caractères. Un index doit représenter le meilleur compromis possible entre ces informations. 
L'article propose un mode de raisonnement permettant :

- Une représentation aisée des résultats des différentes méthodes actuellement existantes pour ce faire.

- La détermination par tâtontrements de compromis plus nuancés.

- La prise en compte dans le compromis des possibilités d'évolution génétique de la souche limitées par les héritabilités et surtout les corrélations génétiques liant les caractères.

\title{
III. - Effets secondaires indésirables de la sélection
}

\author{
EFFETS SECONDAIRES INDÉSIRABLES DE IA SÉLECTION CHEZ LES BOVINS \\ POUR IA PRODUCTION DE VIANDE \\ F. MÉNISSIER \\ Dpt de Génétique animal, C.N.R.Z., 78380 Jouy-en-Josas, France
}

L'amélioration génétique des bovins s'oriente de plus en plus vers la procréation d'animaux spécialisés (lait ou viande) et à fort potentiel de production, destinés à être exploités intensivement. Très efficace à court terme, une telle orientation est assortie de nombreux effets secondaires indésirables.

Ces effets indésirables résultent d'abord de la spécialisation des objectifs de sélection qui, du fait des oppositions biologiques et économiques entre caractères génétiquement liés, entraîne des réponses indirectes défavorables sur les autres critères de productivité et notamment sur les qualités d'élevage : c'est le cas des difficultés de vêlage, conséquence de l'accroissement du potentiel de croissance musculaire, pour lesquelles nous montrons les répercussions sur la poursuite de la sélection. L'efficacité croissante des systèmes de croisement et schémas de sélection conduit à une réduction de la variabilité génétique globale et à des pertes de combinaisons génétiques originales. La disparition de populations locales, l'apparition d'interactions génotype $\times$ milieu, la dérive génétique et l'accroissement de fréquence de gènes majeurs à effets secondaires défavorables, sont les risques les plus importants. Analysé dans ses incidences, son déterminisme et ses utilisations, le caractère culard fournit un exemple parmi tous ces risques.

Cette analyse tente de montrer comment, d'un côté, nous continuons à accroître le potentiel de croissance musculaire des bovins et, de l'autre, nous remédions avec une certaine efficacité aux conséquences indésirables d'une telle sélection. Si l'on y prend garde, à terme, nous risquons d'aller vers un antagonisme de plus en plus grand qui pourrait devenir irréversible pour cette espèce.

\section{SIDE EFFECTS OF SELECTION IN LABORATORY ANIMALS \\ R. C. ROBERTS \\ ARC Unit of Animal Genetics, Institute of Animal Genetics, West Mains Road, Edinburgh EH9 $3 \mathrm{JN}$, Scotland}

The biological causation of correlated responses is considered, and the side effects of selection for body weight in the mouse are examined from this viewpoint. Genetic variation in food intake and in gross efficiency have been clearly demonstrated, with the former perhaps of greater significance. Increases in lean tissue mass seem to be commonly associated with increased fatness, particularly in older animals. The reason for this may be that selection for early growth, before much fat is accumulated, requires a high food consumption, which is not correspondingly reduced as the accretion of lean tissue slows down. The reduced reproductive capacity of large mice, especially females, appears to be largely a consequence of their fatness, though the increasing homozygosity, arising from selection, may also contribute. It is suggested that the undesirable side effects of selection for weight gain should be controlled by restricting the food intake of the selected animals, on the grounds that the genetic separation of the manifold effects would be difficult and inefficient. 